\title{
Beach landscape management as a sustainable tourism resource in Fernando de Noronha Island (Brazil)
}

Samanta da Costa Cristiano; Gabriela Camboim Rocketta; Luana Carla Portz; José Rodrigues de Souza Filho

\section{Abstract}

The Coastal Scenery Evaluation System was used to analyze the landscape of touristic beaches at the Fernando de Noronha Archipelago, using a checklist with 26 physical and human parameters. The beaches are divided into classes ranging from 1 (extremely attractive natural site) to 5 (unattractive urban areas). The data reflects the natural and anthropogenic characteristics of the coastal Noronha scenery, which have international relevance and are between classes $1-4$. Class 3 and 4 beaches are associated with anthropogenic factors/parameters. Seasonal sedimentary stock variation has also contributed to the differences in classes between the seasons at some beaches. The results of this study are useful to create new perspectives for sustainable development based on the singularities of this touristic resource - the landscape. The Fernando de Noronha Archipelago depends on its landscapes for tourism. Therefore, government policies should seek the sustainable management of its beaches, so as to ensure the protection of natural and cultural resources.

\section{Keywords}

Conservation units; Coastal scenarios; World natural heritage; National heritage. 